\title{
LOS VILLANCICOS DE MOJIGANGA DEL MONASTERIO DE LAS DESCALZAS: LOS LÍMITES DE LA TRANSGRESIÓN ${ }^{1}$
}

\author{
Eva Llergo Ojalvo \\ Universidad Camilo José Cela / Antonio de Nebrija \\ ellergo@ucjc.edu / ellergo@nebrija.es
}

\section{LA MOJIGANGA, EL VILLANCICO Y SUS RELACIONES}

ntes de comenzar con el motivo central de nuestra investigación, los vi-
llancicos de mojiganga del Monasterio de las Descalzas, conviene de-
dicar algunas líneas a delimitar los dos términos centrales de nuestra

Comencemos con el primero. Buezo define la mojiganga como «un texto breve en verso, de carácter cómico-burlesco y musical, con predominio de la confusión y del disparate deliberados explicables por su raigambre esencialmente carnavalesca, representado para fin de fiesta» (Buezo 2005: 5). Con esta definición, apunta no solo la mojiganga como subgénero teatral breve sino que recuerda también sus orígenes callejeros y parateatrales. Al mismo tiempo deja patente la evidente traslación del término (o de su espacio de acción) que sucedió desde los años 30 del siglo XVII hasta los mismos decenios del siglo XVIII (2005: 3).

De su pariente parateatral, la mojiganga puramente callejera, la variante dramática hereda probablemente el uso del estribillo, el mote de cada personaje, los tipos propios del Carnaval, los bailes, la música, la indumentaria, los instrumentos, etc. La seña distintiva de la mojiganga teatral será pues la creación de un diálogo mediante el que interactúan los diferentes personajes presentados (Buezo 1991: 363).

\footnotetext{
1 La presente investigación se enmarca y ha sido posible gracias al Proyecto de investigación UCMSantander: «Literatura en el claustro. Poesía, teatro y otros géneros (híbridos) en un convento de fundación real de la Edad Moderna: las Descalzas Reales de Madrid» (26/16-20298), dirigido por Esther Borrego Gutiérrez.
}

Edad de Oro, XXXVII (2018), pp. 138-167, ISSN: 0212-0429 - ISSNe: 2605-3314 
Sin embargo, de entre sus orígenes callejeros pueden rescatarse numerosas variantes de mojiganga, y todas ellas afectaron e influyeron de una manera $\mathrm{u}$ otra a su paso a la variante puramente teatral. Buezo (1991: 182-183) señala las relaciones establecidas entre «los participantes en la fiesta pública que auspician la mojiganga callejera, los locales o edificios de representación y los tipos de mojiganga dramática que temáticamente parecen guardar relación con ellos». Serían:

1. Mascarada de autoridades, nobles, caballeros, realeza que se celebra en localizaciones cortesanas y que da lugar a la mojiganga dramática palaciega vinculada a las fiestas cortesanas y burlescas.

2. Mascarada estudiantil en colegios, universidades que propicia el surgimiento de la mojiganga dramática estudiantil.

3. Mascarada del vulgo en tablados improvisados, calles, plazas, que da lugar a la mojiganga dramática improvisada sobre costumbres populares.

4. Espectáculos de toros y cañas en espacios taurinos, que evolucionan hacia la mojiganga dramática entremesada con fin taurino.

5. Mojiganga eclesiástica y conventual en carros de autos e interiores de los templos o conventos que evoluciona hacia la mojiganga dramática en forma de villancico.

De todas ellas, nuestra investigación se centrará en las últimas. Buezo (1991: 359) afirma que los primeros testimonios de villancicos «cuasidramático» o «dramáticos» se dan en los villancicos del ciclo navideño. Y no solo esto, sino que también serán las muestras más longevas y fosilizadas de este especial género. Buezo (1991: 360) estudia el corpus de pliegos de villancicos conservados entre 1637 y 1756 de la catedral de Toledo y confirma que desde la fecha más temprana (1637) ya hay constancia del uso de los villancicos de mojiganga.

Nuestras propias investigaciones ${ }^{2}$ confirman la temprana aparición de los villancicos de mojiganga desde los primeros pliegos conservados ${ }^{3}$ : en la Real Capilla de Madrid el primer villancico de mojiganga conservado data de $1653^{4}$, en el

2 Hemos estudiado profundamente el corpus de villancicos dramáticos de la Real Capilla (Llergo 2017: 277-425), el Monasterio de la Encarnación (2013) y las Descalzas (2012).

3 Los pliegos más tempranos que conservamos impresos son de 1612 y 1613 de la catedral de Sevilla. Madrid comenzó la costumbre en 1640 (toda la cronología de la expansión de la impresión de los pliegos por España puede verse en Torrente, 2009). Aunque sabemos que la costumbre de insertar canciones en romance durante las liturgias existían desde, al menos, 1418 (Stevenson 1960: 120).

4 Y el primer pliego conservado, en este caso manuscrito, es de 1641 (Llergo 2017: 91 y 323). 
Monasterio de la Encarnación madrileño de $1676^{5}$ y en el corpus que ahora manejamos para el presente estudio, los pliegos de villancicos del Monasterio de las Descalzas, desde el segundo pliego conservado, el de la Navidad de 1679.

Cuando hablamos de «villancicos paralitúrgicos» conviene recordar que pueden distinguirse entre ellos dos tipologías: aquellos de índole más lírica, más apegada al lenguaje y las formas de la liturgia donde se insertan; y los de vertiente teatral, que emparentan en formas y contenido con los subgéneros teatrales breves del Siglo de Oro. Obviamente, dentro de estos segundos enclavamos nuestros villancicos de mojiganga. Así pues, si hablamos de porcentajes de representación dentro del corpus de villancicos teatrales estudiados de estas tres instituciones religiosas madrileñas, observamos que en los pliegos conservados del siglo XVII los villancicos de mojiganga en la Real Capilla configurarían un 15\% del total de los teatrales, en el Monasterio de la Encarnación un 20\% y en el de las Descalzas un 54\% (Llergo 2013: 209).

Por otra parte, la teatralidad se hace evidente de diferentes maneras en los villancicos. Unas veces, como en el caso de los villancicos de jácara, se explicita como nombre de sección en los propios pliegos. Otras veces, como en el caso de los villancicos de mojiganga que nos ocupan, son los propios textos los que nos avisan del parentesco en la mayoría de los casos:

Dos tórtolas gemidoras mostró que, vistas de cerca, eran dos beatas y hallose con la mojiganga hecha ${ }^{6}$.

$\mathrm{Y}$, asimismo, muestran conciencia con las partes propias de la mojiganga, como el mote:

En su adarga la rosa
lleva una cifra
con un mote que dice
«Rosa es María»

Otras muchas veces aparece autodenominada con otros de los cuasisinónimos de la mojiganga: encamisadas, mascaradas, etc. (Buezo 1991: 184). En otras muchas ocasiones el término es obviado por completo dentro de las composiciones,

\footnotetext{
5 En este caso se trata del cuarto conservado, siendo el primero de 1649 (un insólito pliego compartido con la Real Capilla), y los siguientes de 1671 y 1675 (Llergo 2013: 205).

6 Fragmento del villancico II de la Navidad de 1692 de nuestro corpus.

7 Fragmento del villancico VI de la Navidad de 1696 de nuestro corpus.
} 
pero se observan huellas claras de la conciencia compositiva del género. Así pues, la estructura más habitual en los villancicos de mojiganga es la basada en la entrada de personajes y presentación de sus caracteres y/o entrega de presentes. Habitualmente este desfile tiene, además, otra intención secundaria: requiebros al Niño recién nacido a través de los personajes que pasan por el portal, alabanzas al monarca a través de un desfile de naciones, intenciones catequéticas mediante el repaso de personajes bíblicos, etc.

Por otro lado, la aplicación de la mojiganga en el villancico es variable y gradual. En muchos casos, esta noción de desfile se diluye hasta emborronar los conceptos escénicos de «entrada y salida» de personajes, convirtiendo el desfile más bien en un repaso de situaciones que simplemente se dan ante los ojos del narrador/cantor, que este nos cuenta en tercera persona. En este primer tipo no aparece de ningún modo el tradicional mote. Hablaríamos así de un primer tipo de villancico de mojiganga, el más alejado de su pariente teatral: la mojiganga dramática.

En un segundo nivel, encontraríamos aquellos villancicos de mojiganga que usan la tercera persona (el narrador/cantor que nos ilustra sobre la entrada y la salida de los personajes), pero también dan paso, en la mayoría de los casos, al uso de la primera persona por parte de los integrantes del desfile. Esta se alterna, además, con una tercera voz que ofrece un mote o conclusión sobre la condición del personaje que desfila y que, en muchos casos, incluye un misterio o alusión por descifrar.

El último tipo de villancico de mojiganga entroncaría de manera más directa con su pariente teatral, la mojiganga dramática, haciendo uso de la entradilla de personaje habitual del formato dramático. Eso sí, nunca ofrecerán una verdadera interacción entre sus personajes ni el desarrollo de una auténtica acción dramática, como sí sucedía en la mojiganga teatral.

Así pues, es evidente, como señala Buezo (1991: 354), que el villancico de mojiganga heredó tanto características de la mojiganga callejera (la parateatral) como de la dramática. Por ello, cuando hablamos de tipo 1 y 2 , donde la teatralidad se muestra más distanciada, estos villancicos entroncarían más con la vertiente callejera, como si un cronista o espectador las estuviera narrando aunque, en determinados momentos, pudiéramos escuchar la voz de los propios miembros del desfile en estilo directo. Mientras que el tipo 3 da soporte a la mojiganga en su vertiente más teatral, asemejándose de manera directa con su pariente dramática aunque con las limitaciones propias del género «villancico» que le imposibilita para dar cabida a una verdadera acción teatral.

Ahora que hemos revisado las circunstancias en las que la mojiganga se implantó en el villancico, pasaremos a analizar pormenorizadamente cómo se fraguó esta costumbre en el madrileño Monasterio de las Descalzas durante los siglo XVII y XVIII. Partimos del dato de que de todos los corpus de villancicos de los que 
se ha estudiado particularmente su teatralidad, el Monasterio de las Descalzas es el que auspició especialmente el cultivo y desarrollo del villancico de mojiganga configurando, como hemos explicado en las páginas precedentes, el 54\% del total de los villancicos teatrales en el siglo XVII.

Tal predominancia debió deberse, a nuestro juicio, al especial gusto de los fieles por este género que debió de convertirlo en «marca de la casa» dentro del corpus de villancicos de las Descalzas Reales, como había sucedido en otros corpus con un personaje (el villancico de asturiano del Monasterio de la Encarnación [Llergo 2013: 217-218]) o con una cifra singular de villancicos por pliego (los siete villancicos de la Real Capilla [Llergo 2017: 136]).

Para contemplar con mayor amplitud este fenómeno estudiaremos ahora también el corpus conservado del siglo XVIII.

\section{Los villancicos de mojiganga de las Descalzas en el siglo XVII}

Conservamos 18 pliegos de villancicos del siglo XVII: el primero de 1679 y el último de 1699. Entre ellos hay algunos pliegos dobles que recogen las festividades de Navidad y Epifanía ${ }^{8}$. Además de las festividades de Navidad y Epifanía, a modo anecdótico encontramos el primer pliego destinado a celebrar la fiesta del Santísimo Sacramento. Pero, como decimos, es el único de su especie entre todos los pliegos conservados de los dos siglos.

El número de villancicos por pliego no es homogéneo como sí lo era en otras instituciones religiosas (Llergo 2017: 135). Se puede advertir cierta tendencia a incluir diez, uno por cada responsorio del oficio de maitines y otro más para la adoración. Pero no son anecdóticas las ocasiones en que aparecen durante este siglo siete, ocho o nueve en los dedicados a la Navidad. En los pliegos de Epifanía hay aún más heterogeneidad pues llegan a darse casos con cuatro o cinco villancicos por pliego.

Por otro lado, en el corpus del siglo xvII raro es el pliego en el que no se incluya ningún villancico de mojiganga ${ }^{9}$. En el resto de ocasiones se observa una altísima representación del género: cuatro pliegos (las Navidades de 1685, 1691, $1692,1699)$ contienen cinco mojigangas; cuatro mojigangas en la Navidad de 1694; tres pliegos (las Navidades de 1682, 1690, 1693) tienen tres mojigangas; cinco años tienen dos mojigangas (las Navidades de 1679, 1683, 1695, 1696 y los Reyes de 1690); cuatro años contienen una mojiganga (la Navidad de 1680, 1683,

\footnotetext{
8 Se tratan de los pliegos de la Navidad de 1682-Reyes de 1683, Navidad de 1683-Reyes de 1684, Navidad de 1684-Reyes de 1685 y Navidad de 1685-Reyes de 1686.

$9 \quad$ Sucede únicamente en la Navidad de 1678 y en los Reyes y en la Navidad de 1684.
} 
$1686,1688)$. Contamos, pues, con un total de 46 villancicos de mojiganga en los pliegos conservados de este año.

Si analizamos los tipos de mojiganga que contienen estos pliegos, observamos que hay una predominancia clara del tipo 2 (treinta y cinco villancicos); mientras que el tipo 1 solo cuenta con seis casos y el tipo 3 con cinco.

Veamos sus particularidades dentro de cada grupo. Dentro del primer tipo podemos ofrecer como un representante puro el villancico III de las Navidades de 1685 donde asistimos a la narración de los miembros del desfile dentro del portal; sin mote y sin intromisión alguna del estilo directo, pero sí atendiendo al disfraz, incluso al baile con el que van desfilando:

Entró un pastor con arnés
de color vario el matiz,
puntas de ojo de perdiz
al derecho y al revés,
con vara y media de pies
y sin hilo de camisa
y reventaban todos de risa.
Entró un zagal arrogante
con pollera de albornoz,
y a cada cual dio una coz
con el pie del guardainfante;
una trompa de elefante
llevaba el tal por divisa
y reventaban todos de risa.
Entró después la chacona
con basquiña de picote
desde los pies al cogote
bordada de piel de mona
y al pescuezo una valona
sin escote y toda sisa
y reventaban todos de risa.
Entro luego Juan de Araña ${ }^{10}$
pidiendo mucha atención,
a darle al buey un rejón
caballero en una caña,
pero el buey con linda maña
lo echó con furia improvisa.
y reventaban todos de risa $[\ldots]^{11}$.

10 Según Huerta y Alonso Hernández (2000: 84-85), con el nombre Juan de Araña se alude jocosamente a un ladrón. Además, documenta el uso de este personaje en otros villancicos.

11 Fragmento del villancico III de la Navidad de 1685. 
Del resto de los villancicos de mojiganga del tipo 1 de nuestro corpus de las Descalzas, nos gustaría señalar también el villancico VIII de Navidad de 1692 como un ejemplo de la experimentación con sus formas y planteamientos. En este la narración del desfile se enmarca en la petición de Bras y Antón, pastores habituales en los villancicos, de cambiar la tradicional danza de panderos, sonajas, flauta y tambor por una nueva danza: unos matachines ${ }^{12}$. En el fragor de la danza, Bras y Antón van dando nota de quién entra en el portal:

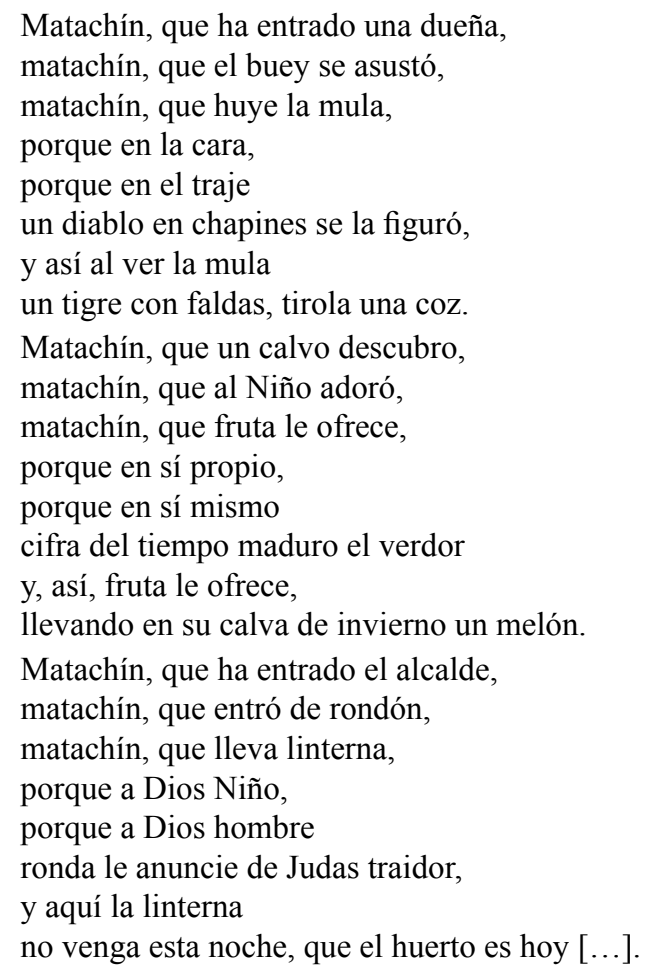

Pasemos ahora al tipo 2, donde la primera y la tercera persona se alternan en la presentación de los personajes y el mote aparece con frecuencia después de su desfile. El corpus de las Descalzas nos ofrece ejemplos muy notorios de experimentación con las formas, contenidos y planteamientos a través de los cuales se

12 Matachín: «Hombre disfrazado ridículamente con caratula, y vestido ajustado al cuerpo desde la cabeza a los pies, hecho de varios colores, y alternadas las piezas de que se compone: como un cuarto amarillo y otro colorado. Formase destas figuras una danza entre cuatro, seis o ocho, que llaman los matachines, y al son de un tañido alegre hacen diferentes muecas, y se dan golpes con espadas de palo y vejigas de vaca llenas de aire» (Autoridades, 1734). 
propicia el desfile. Estas innovaciones se hacen más patentes a medida que avanzamos cronológicamente por los pliegos conservados del siglo XVII. Como hemos mencionado, es tan evidente que hace pensar que este tipo de villancicos era el preferido del auditorio de las Descalzas ${ }^{13}$, ya que esta búsqueda incesante de novedad parece lógico achacarla a la intención de complacer al entregado auditorio.

En los primeros pliegos conservados, podemos observar una estructura y planteamiento de los villancicos de mojiganga relativamente estandarizada: basada en el desfile de personajes ante el portal que vienen a requebrar al Niño. Sería ejemplo representativo el villancico II del pliego de la Navidad de 1682. En este caso los requiebros se mezclan con otro tipo de afirmaciones espontáneas que configuran una estampa costumbrista y llena de humor:

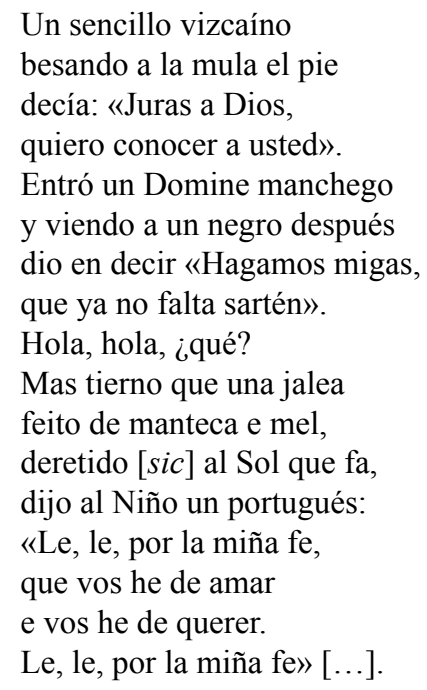

Si avanzamos un poco más en el tiempo, el villancico IV del pliego de las Navidades de 1685 podría ser otro ejemplo de búsqueda innovadora de planteamiento. En este caso son árboles los que desfilan ante el Niño para ofrecerse a fabricar una cuna con sus maderas a la imitación de san José. Ante sus ofrecimientos el coro expresa su opinión sobre si el árbol en cuestión merece o no tal privilegio:

COPLAS

1. Los árboles, deseosos

de ser materia capaz

\footnotetext{
13 Intuición avalada también porque, como hemos comentado, el número de villancicos de mojiganga del Monasterio de las Descalzas es notablemente superior al de otros corpus estudiados.
} 
para fabricar un catre, pretendientes vienen ya:

zas, zas, zas.

Que si el tiempo los árboles tiene desnudos de galas y de vanidad servirá el corazón en la obra, porque es el que en ella se puede labrar: a serrar, a serrar, a serrar.

2. El pino por más común el primero quiso entrar, que aunque no es madera noble, suele ser la principal:

zas, zas, zas.

Y ermitaño en los montes el pino celebre el misterio de su soledad, que no sirve a un pimpollo que nace quien de producirlos ha sido incapaz: a serrar, a serrar, a serrar, maderita en el portal.

3. El ciprés ufano intenta rendir todo su caudal y si ha de vencer lo altivo mucho tiene que arrojar:

zas, zas, zas.

Pues viene con traje funesto, cuando cielo y tierra festivos están. Váyase con mortales anuncios a ser tumba triste de algún hospital.

A serrar, a serrar, a serrar, maderita en el portal [...].

El siguiente ejemplo (villancico II de la Navidad de 1692) narra la aparición de un titiritero que durante la representación de su espectáculo muestra diferentes marionetas y objetos que se van transformando simbólicamente en personajes. Tras la narración de la aparición, el coro glosa un pequeño comentario a modo de mote sobre lo que el Niño aprecia del personaje aparecido tras la transformación. Nos parece un ejemplo interesante de juego metaficcional, del que el género villanciquero es muy aficionado, y que, en este caso, toma ciertos toques surrealistas no exentos de filosofía:

1. Sacó el jugador de manos

tres pelotillas de cera

y luego danzando salen 
tres sacristanes de ellas.

Opilados ${ }^{14}$ de cera

al niño hablaron

porque les dé remedio

que andan al cabo ${ }^{15}$.

2. Luego con presteza grande

mostró una sierpe tremenda,

y al darla [sic] una vuelta solo

se halló convertida en suegra.

Mas consuela que el Niño

vencer previene

los daños que vinieron

por una sierpe.

3. Una calavera triste

a los que le atienden muestra,

y salió de ella un doctor,

con su sortija y su pera.

La alusión dice al Niño

que es vida y norte

que le hallarán perdido

entre doctores ${ }^{16}$.

El villancico III de la Navidad de 1693 es otra muestra del enrevesamiento argumental tan propio de los villancicos de mojiganga. En él los pastores con el fin de entretener al Niño traman el juego de los oficios. Su desarrollo consiste en que todos los oficios del pueblo comparezcan ante el niño y «pierdan su asiento» aquellos que se metan en oficio ajeno ${ }^{17}$. El fundamento del villancico se basa en la entrada por parejas de los representantes de los oficios; ambos son depositarios de vicios o defectos asociados al desempeño de cada trabajo y se trata de que el coro dirima quién es el culpable. El villancico nos parece especialmente teatral

14 'Opilar': «Obstruir, tapar y cerrar los conductos del cuerpo humano, de suerte que no corran libremente los espíritus» (Autoridades, 1737).

15 Dilogía entre la locación adverbial «al cabo» y el sustantivo «cabo» entendido como el pedazo de vela que queda tras ser gastada la mayor parte de ella que hace alusión, a su vez, a una de las funciones habituales de los sacristanes que era encender y apagar las velas de las iglesias.

16 Alusión al pasaje bíblico conocido como «Jesús entre los doctores» o «Jesús perdido y encontrado» en el templo, donde se cuenta el efecto que su presencia causó entre los teólogos y doctores de la Ley mosaica (Lucas 2: 41-50).

17 Meterse en oficio ajeno: «Frase con que se reprende al que se incluye en algo que no le toca» (Autoridades, 1737). Al mismo tiempo «el juego de los oficios» es otro de los nombres con lo que se conoce el juego tradicional «Antón Pirulero» donde cada participante debe mimar el oficio que está representando. 
puesto que, aunque no tiene la entradilla de personaje que nos haría colocarlo en la tercera tipología de villancicos de mojiganga, esta es fácilmente reconstruible y la práctica totalidad del texto está enunciado en primera persona:

\begin{tabular}{|c|c|}
\hline 1. [AGUADOR] & $\begin{array}{l}\text { Señor, yo soy de Belén } \\
\text { aguador y el tabernero, } \\
\text { con mudarle solo el nombre, } \\
\text { me vende lo que le vendo }{ }^{18} \text {. }\end{array}$ \\
\hline 2. [TABERNERO] & $\begin{array}{l}\text { Que soy mercader de agua } \\
\text { es verdad, yo lo confieso, } \\
\text { mas si la compro desnuda, } \\
\text { qué mucho la venda en cueros. }\end{array}$ \\
\hline 3. [CORO] & $\begin{array}{l}\text { Truequen, truequen sus asientos } \\
\text { Mas que al vino no puedan } \\
\text { se les encarga, } \\
\text { porque no ande desnudo } \\
\text { ponerle enaguas }{ }^{19} \text {. }\end{array}$ \\
\hline 1. [SASTRE] & $\begin{array}{l}\text { Señor, aunque yo soy sastre } \\
\text { del escribano me quejo } \\
\text { porque yo ajusto jubones } \\
\text { mas él ajusta el coleto }{ }^{20} \text {. }\end{array}$ \\
\hline 2. [EsCRIBANO] & $\begin{array}{l}\text { Es verdad que la medida } \\
\text { les tomo por el proceso, } \\
\text { mas entre escribano y sastre } \\
\text { no sé quién tiene buen pleito. }\end{array}$ \\
\hline 3. [CORO] & $\begin{array}{l}\text { Truequen, truequen sus asientos } \\
\text { Entre los dos oficios } \\
\text { poca es la duda } \\
\text { puesto que el uno viste } \\
\text { y ambos desnudan }[\ldots] .\end{array}$ \\
\hline
\end{tabular}

Por último, traemos a colación otro ejemplo de villancico de mojiganga con gran complejidad argumental. Se trata del villancico V de la Navidad de 1696. El

\footnotetext{
18 El aguador acusa al tabernero de venderle el mismo producto que él le ha proporcionado, agua, pero con el nombre cambiado, vino. Alusión a la proverbial costumbre de los taberneros madrileños a aguar el vino.

19 Calambur (poner el vino «en-aguas») con el que el coro reprende la costumbre de aguar el vino.

20 El coleto, como el jubón, son prendas de vestir, pero con la frase «coger, pescar o pillar el coleto se da entender que a alguno le cogieron de manera que no pudo escapar» (Autoridades, 1729). En este caso, figuradamente se hace alusión a los honorarios que debían cobrar los escribanos que comprometían la economía de quienes requerían sus oficios: «Nos tienen ya en cueros, y en la quinta esencia de la necesidad, solicitadores, procuradores y escribanos, de quien Dios Nuestro Señor nos libre» (Cervantes, Los trabajos de Persiles y Sigismunda, libro 4, cap. 5).
} 
detonante es una rifa que las zagalas pretenden hacer para celebrar el nacimiento del Niño. El premio será el buey del pesebre y el desfile lo configuran la procesión de personajes interesados en la rifa que echan sus cédulas ${ }^{21}$ para el sorteo:

\author{
Al sorteo del buey entró un calvo \\ como por la palma ${ }^{22}$, \\ que aún mejor, que no al buey, a la mula \\ en pelo ${ }^{23}$ tomara. \\ 1. Lean la cédula. \\ 2. Óiganla. 3. Vaya: \\ «Don Calvatrueno Copete \\ vive en la misma fachada, \\ en casa de un melenero ${ }^{24}$ \\ en el Horno de la mata $^{25}$ 》. \\ Blanca, blanca. \\ Poca dicha ha tenido \\ $\mathrm{y}$, según veo, \\ desde ahora no espere \\ le cubra el pelo. \\ Un gran casamentero ha venido con suerte ${ }^{26}$, \\ y me cuadra \\ porque el buey siempre ha sido en sorteos \\ de capa y espada. \\ 1. Lean la cédula. \\ 2. Óiganla. 3. Vaya:
}

21 'Echar cédulas': «Sortear sobre alguna cosa: como la noche de año nuevo que sortean santos, damas y galanes, escribiéndose los nombre en unas cedulitas pequeñas, las cuales se dobla y después de revueltas se van sacando, primero la del galán, después la de la dama y el santo que les toca tener especial devoción aquel año. Lo mismo se ejecuta en los lugares, cuando se sortea quién ha de ir por el soldado, y en las rifas para saber a quién ha de tocar la alhaja» (Autoridades, 1729).

22 'Como por la palma de la mano': «Modo de hablar con el que se significa la facilidad de ejecutar o conseguir alguna cosa» (Autoridades, 1737).

23 'Pelo': «Se toma también por el color de la piel de los animales, especialmente en mulas y caballos» (Autoridades, 1737).

24 Posible alusión al trabajador que se ocupa de hacer las «melenas» entendida como la «piel blanda que se pone al buey en la frente para que no se lastime con el yugo» (Autoridades, 1734).

25 Horno de la mata era una calle del centro de Madrid. Aquí se hace un juego dialógico entre el nombre de la calle y el uso translacticio de «mata» por «cabello» (Autoridades, 1734).

26 'Suerte': «Se llama la cédula en que se escriben los nombres de los que entran en rifa a alguna alhaja» (Autoridades, 1739) y también «en las fiestas de toros vale la burla que se les hace poniéndose delante de ellos y librándose con habilidad y ligereza» (Autoridades, 1739). El uso dialógico del término «suerte» justifica la actitud «toreadora» del casamentero ante la siguiente mención de la actitud con la que el buey aborda el sorteo defendiéndolo «a capa y espada». 


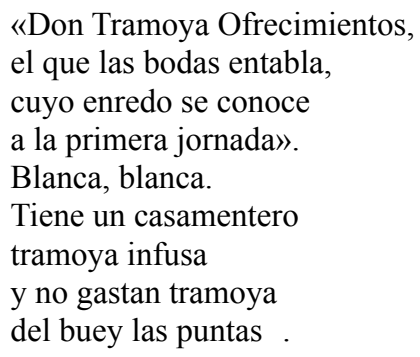

A través de estos ejemplos y teniendo en cuenta la frecuencia y cantidad de villancicos de mojiganga en los pliegos de las Descalzas del siglo XVII, queda patente que esta tipología de villancico debía de ser la más solicitada por el público del Monasterio; su «marca de la casa». Sus autores buscaron satisfacer las expectativas de novedad de los oyentes con sorprendentes propuestas argumentales, intromisión de nuevos personajes y metaforizaciones, en consonancia - además - con la evolución natural que las mojigangas callejeras estaban tomando (Buezo 1991: 185).

\section{Los Villancicos De mojiganga de las Descalzas EN El Siglo XVIII}

El análisis de los pliegos conservados del siglo XVIII indica la consolidación que el género del villancico experimentó en la institución. Conservamos una cifra muy superior de pliegos de villancicos: $32^{28}$. Aunque bien es cierto que, como puede verse en el listado final del corpus utilizado de pliegos del XVIII, los villancicos en este siglo se estuvieron imprimiendo prácticamente de forma ininterrumpida durante 50 años, mientras que en el siglo XVII apenas fueron 20 años (1679-1699). La frecuencia de conservación en ambos casos es, por lo tanto, similar: prácticamente uno por año. Con la salvedad de que en el siglo XVII durante varios años (1682-1686) se estuvieron imprimiendo pliegos dobles para celebrar la Navidad y la Epifanía, y también conservamos algún pliego suelto posterior para celebrar los Reyes (1690). La costumbre de celebrar la festividad de Reyes en el siglo XVIII

27 Alusión a que aunque las tramoyas «metafóricamente vale enredo hecho con ardid y maña o apariencia de bondad» (Autoridades, 1739) sean algo inherente a los casamenteros, en este caso el buey no lo ha necesitado cuando ha hecho uso de sus «puntas». Esto último hace alusión a la coz con la que ha debido de ser despedido el casamentero por la bestia que, en este caso, no tenía ninguna pretensión de aparentar bondad o delicadeza con el casamentero. De aquí que no tenga tramoyas.

28 Frente a los 18 conservados del siglo XVII. Aunque hay que recordar que la costumbre de cantar villancicos (o incluso tal vez estemos hablando solo de imprimir los pliegos), debió de cuajar tarde en la institución, pues el primer pliego conservado del siglo XVII es de la tardía fecha de 1679. 
se atenuó o se excluyó de la impresión a juzgar por los pliegos conservados. Solamente se conservan dos pliegos de 1700 y 1710 dedicados a la Epifanía durante este siglo. De modo anecdótico nos encontramos un pliego de 1708 destinado a una profesión religiosa.

La interrupción de la impresión en 1749 pudo deberse principalmente, según Torrente (2010: 216-217) a la encíclica Annus qui hunc de Benedicto XIV promulgada el 19 de febrero de 1749 donde se prohibían los «moteti volgari». Parece significativo que las tres instituciones religiosas de patronato real de la época, la Capilla Real, el Monasterio de la Encarnación y de las Descalzas interrumpieran la costumbre de imprimir los pliegos en la misma fecha ${ }^{29}$.

El número de villancicos por pliego en el siglo XVIII es otra de las muestras de consolidación de la identidad de los villancicos de las Descalzas. En los primeros años observamos aún cierta vacilación, con pliegos que contienen cuatro villancicos $(1700,1710)$, ocho más el dedicado a la adoración (1701) o diez más el de la adoración (1708). Sin embargo, a partir de 1711 (y también de forma aislada en 1703) se recupera la tendencia comenzada en el siglo XVII de incluir nueve villancicos más el dedicado a la adoración en todos los casos.

Sin embargo, si nos fijamos ahora en los villancicos de mojiganga, el panorama es muy distinto al dibujado en el siglo XVII. En los primeros años se observa una tendencia similar a su inclusión: el pliego de 1700 contiene dos villancicos de mojiganga, 1701 tiene uno y 1702 y 1703 incluyen dos. Pero, al fijarnos en el pliego de 1708, tras el lapso que suponen los años de 1704 a 1707 de los que no conservamos ningún pliego, encontramos que no incluye ningún villancico de mojiganga. Reaparecen tres de ellos en el pliego de 1711, con su antigua fuerza; después en 1713 y 1715 tímidamente con uno. Y lo que sigue es un silencio absoluto y sorprendente, pues hasta 1736 no vuelve a aparecer en ningún pliego un villancico de mojiganga. Además, su inclusión ahora ya es anecdótica en los pliegos: uno $(1736,1739,1740,1744,1746)$ o dos $(1738,1747)$ villancicos de mojiganga tan solo. También se vuelve más frecuente su ausencia total en algunos años $(1737,1741,1743,1745,1748,1749)$.

Al mismo tiempo, se percibe la intromisión (si no sustitución) de nuevas formas como las tonadillas y las pastorelas. Muchas veces definidas como un solo subgénero de villancico, en realidad las tonadillas y las pastorelas ostentan diferencias significativas. Ramos (2007: 286) afirma que el signo más definitorio de las pastorelas consistía en ser canciones en primera persona puestas en boca de pastoras jóvenes. Pérez Mora (2006: 31), por su parte, confirma que en el caso de la tonadilla la gama de personajes era más amplia; podían aparecer pastores

29 El último pliego conservado de la Real Capilla es de la Epifanía de 1750, exactamente igual que de la Encarnación. El de las Descalzas es el de la Navidad de 1749 (Torrente 2010: 216). 
pero también gallegos, negros, asturianos, etc. Por otro lado, ambos tipos de villancico irrumpen con fuerza en el siglo XVIII, dentro de las renovaciones formales y temáticas que transforman al villancico durante esta centuria. Sánchez Siscart (1989-1990: 337) opina que, como contrapunto a la moda italianizante que llenó los villancicos de arias y recitados, los villancicos de pastorela y tonadilla sirvieron como equilibrio para recuperar el sabor más nacional y tradicional que habían tenido el villancico, pero de una forma renovada ${ }^{30}$.

Como apuntan Ramos (2007) y Pérez Mora (2006), es innegable la teatralidad de los villancicos de pastorela y tonadilla, pues estos últimos reemplazan, en muchos casos bajo una forma musical concreta (la de la tonadilla), la habitual estructura de villancico de personaje, otra de los tipologías en las que se muestra el parentesco del villancico con los subgénero teatrales breves en el siglo XVII. No obstante, los villancicos de personaje no habían tenido una adscripción musical tan concreta en dicha centuria (Llergo 2017: 332-386) como sí lo mostraron en el XVIII los villancicos de tonadilla y pastorela. Su estructura teatral es innegable, aumentando incluso las intervenciones dialogadas respecto a los villancicos de mojiganga, gracias a las réplicas que el coro le da al personaje que interpreta la parte principal. Sin embargo, es también innegable que, temáticamente, tanto las pastorelas como las tonadillas, conservan siempre un fuerte apego al ámbito religioso. Se pierde en ellas en parte el bullicio popular, la representación más puramente costumbrista, humorística y anecdótica de los villancicos de mojiganga.

Cierto es, como señala Ramos (2007: 295), que las pastorelas ostentan otro grado de transgresión en el mundo del villancico, pues son canciones con personajes femeninos que serían representadas por cantores masculinos y, en la mayoría de los casos, eclesiásticos, puesto que, según la investigadora, el canto de mujeres estaba prohibido en las iglesias. Testimonios de viajeros extranjeros nos han dejado constancia de frailes y sacerdotes disfrazados de mujeres durante algunas representaciones religiosas ${ }^{31}$. De modo que Ramos se pregunta si ese «travestismo

30 Ramos (2007) apunta que las distinciones entre villancicos italianizantes y tradicionales o hispánicos no están tan claras y que es complicado adscribir a las pastorelas al segundo tipo, puesto que cuenta con una fuerte tradición paneuropea que lo universaliza en cuanto a sus formas y temas (mientras que Pérez Mora sí remarca el «rebosante hispanismo de las tonadillas» [2006: 49]). Por otro lado, no era infrecuente encontrar villancicos de pastorela o tonadilla que incorporaban secciones italianizantes como los recitados y arias (Sánchez Siscart 1989-90: 335).

Nos referimos a las crónicas de Bertout: «Fui a la misa de medianoche en los franciscanos, donde me consolé de la pérdida que había hecho de no estar en Madrid para ver las comedias que los frailes representaban en su convento, en el coro de su iglesia, esa noche, para regocijarse del nacimiento de Nuestro Señor. Me costaba trabajo creer lo que un librero, en cuya casa compré libros, me dijo, que había dado la comedia El mariscal de Biron, en versos burlescos a un fraile que la debía representar en su convento, y que su mujer había prestado su vestido a uno de ellos para eso. En efecto, vi alguna cosa que valía bien la pena; porque en cuanto abrieron las puertas 
oral» no sería otra manera de trasgresión para seguir atrayendo a la gente a las iglesias con el reclamo de oír no solo a personajes femeninos interpretados por masculinos, sino también disfrazados de ellos. Justo a la inversa de lo que sucedía en los teatros donde uno de los máximos reclamos era ver a actrices representando papeles de hombre.

Sea como fuere, es evidente que los encargados de componer los villancicos y sus letras en el siglo XVIII trataron de sustituir las formas más vinculadas con las transgresiones temáticas flagrantes, los villancicos de mojiganga, por otras más ortodoxas, elitistas y modernas (los villancicos italianizantes). Sin embargo, es muy posible que una vez relegado el tipo de villancico favorito del público de las Descalzas, la asistencia de los fieles se resintiera y se buscara volver a atraerles con otros nuevos tipos de villancico (los de pastorela y tonadilla) que circundaran sus temas y formas de expresión (Pérez Mora 2006: 60) pero sin el desvío temático que suponía los villancicos de mojiganga del siglo XVII.

Ejemplo claro de cómo se quería convencer de esta dislocación al propio público es el villancico de tonadilla (número III) del pliego de las Navidades de 1745. La introducción nos deja claro cómo se vendía al público la función de las tonadillas: son el «turrón de las navidades»; el estribillo refuerza con teatralidad la sensación de fiesta popular, pero luego en las coplas el asunto es estrictamente religioso y nada queda de la transgresión temática de los antiguos villancicos de mojiganga:

\section{INTRODUCCIÓN}

¿De qué sirve en esta noche panderillo y castañuela si la tonadilla falta, que es turrón de la Nochebuena?

Venga aquí toda zagala porque al Niño le diviertan, tengan cuenta, porque Bato ha de ser Perico en ellas.

\section{ESTRIBILLO}

Coro. Vaya, zagales, de chiste y donaire. Vaya, muchachas, de gusto y de fiesta.

Solo. Eso me agrada. Eso me alegra.

de la iglesia, donde esperaba una multitud de pueblo, vi los tamboriles vascos que se ponían acordes con los órganos que tocaban una chacona. Fue aquello la preparación de los maitines, después de los cuales vi a un fraile que llevaba un sobrepelliz, y que después de haber hecho que tenía que hacer en el altar, se quitó el sobrepelliz y se fue a la sacristía para mostrar una casaca de traje de máscaras que llevaba debajo [...]» (García Mercadal 1999, t. 3: 459-460). 
Coro. Suene el pandero y la castañetilla.

Solo. Voto a San, que bailan las piernas.

1. Fuera Simplote.

2. Quita Molenda.

3. Calla Zamarro.

Solo. Pues callen ellas, porque a fe que si empiezo a dar voces, ya verán cómo trueno la iglesia.

A 4. No cantes, calla, que a nuestra cuenta queda el que haya tonada nueva.

Solo. ¿Pues a qué aguardan que no comienzan?

Coro. Vaya, zagalas de chiste y donaire, vaya muchachas de gusto y de fiesta suele el pandero y la casteñetilla [sic] vaya el juguete, que al Niño divierta.

\section{TONADILla}

Solo. Pues la paz nos canta el cielo cuando naces a la Tierra señal que la guerra acaba y que su destierro empieza.

[CORO]. Échala guapo, querido del alma, échala luego, que acá nunca vuelva.

Solo. Échala, y Bato verás cómo baila pues con sosiego no habrá quien no duerma.

Coros. Vaya, que es linda, siga, que es buena.

Uníson[o]. Pues la paz nos canta el cielo cuando naces a la tierra, etc.

El villancico siguiente (IV) del mismo pliego deja huella del agotamiento de inspiración que debían experimentar los autores de las letras; agravado, quizás a partes iguales, por las demandas del público y las censuras de los críticos.

El texto es muy explícito al respecto:

\section{INTRODUCCIÓN}

Como faltan las ideas de letras de Navidades, en Belén los pastorcillos mano sobre mano están. 
Vieron un horno de vidrio, y dijo alegre un zagal: «Para divertir al Niño, buen asunto este será».

El planteamiento, después, se basa en las peticiones de los cantores/zagales de diferentes tipos de vasos de cristal que salen del horno. Dudamos de su adscripción a la tipología del villancico de mojiganga. No obstante, es indudable que se da una situación de tránsito de los cantores ante el horno y que el planteamiento, tan dislocado de lo Navideño como anecdótico, encaja con las fórmulas que solían usarse en los villancicos de mojiganga del siglo XVII. Sin embargo, como vemos a continuación, el desarrollo como tal es plenamente piadoso, aunque el motivo del punto de partida resulte tan peregrino.

\begin{tabular}{cl} 
1. & \multicolumn{1}{c}{ Coplas } \\
Quisiera un vaso muy bello, \\
que no se quiebre jamás. \\
Muchos vasos hay hermosos \\
que se suelen desgraciar. \\
Uno se quebró al terrible \\
golpe de un yerro fatal, \\
de su amor al fuego el Niño \\
de nuevo le formará ${ }^{32}$. \\
Aunque vasos antiguos \\
no dude que habrá \\
mal formados a soplos \\
de su vanidad. \\
Leña partid, \\
el fuego avivad, \\
zas, cis, cis, cis, zas. \\
Barrilla y arena, \\
cerned y amasad.
\end{tabular}

Si nos centramos ya plenamente en los villancicos de mojiganga del siglo XVIII que se interpretaron en las Descalzas, encontramos también que hay un claro predominio del tipo 2 (diecinueve villancicos), una tímida representación del tipo 1 (tres casos) y la desaparición total del tipo 3, recordemos, el de aspecto y contenido más teatral.

\footnotetext{
32 Se utiliza este vaso como metáfora de la creación del hombre. Dios hizo al hombre con barro con sus manos según los textos sagrados; se extiende la metáfora pues a Adán como vasija hecha por Dios que se quebró por el pecado original.
} 
Entre los tres ejemplos encontrados del tipo 1, destacamos el villancico III de la Navidad de 1703. En él asistimos a un desfile de personajes que vienen a obtener un premio que el Niño recién nacido dispone en un árbol. Como puede apreciarse todo en un tono muy sentencioso y admonitorio y despojando a los personajes tipo de sus tradicionales atributos y características, puesto que a lo que la letra da preponderancia es a los yerros cometidos por los personajes del desfile:

\author{
[...] Un portugués ha subido \\ y se está quedo que quedo, \\ sin ir ni abajo ni arriba \\ por más que aguijan. Pero, \\ pero, pero... \\ Pero, ¿qué?, pero, ¿cuándo? \\ Pero a puros silbidos \\ de los muchachos \\ ha caído, maduro, \\ $\mathrm{y}$ atolondrado. \\ 1. ¿Quién le echó el lazo? \\ que le tenían \\ en el aire pendiente \\ de cierta liga. \\ Con un lazo escurridizo \\ subió a la cumbre un logrero ${ }^{33}$ \\ y porque no le estorbase \\ le echó a la garganta. Pero \\ pero, pero... \\ Pero, ¿qué?, pero, ¿cuándo? \\ Pero ya del vestido, \\ desesperado, \\ aunque por él se ahorca \\ se viene abajo. \\ 1. ¿Quién le echó el lazo? \\ pues Dios le vale \\ lo que él quiere, y aún dello \\ se satisface $[\ldots]$.
}

2. Neutralidad, y miedo

2. Desconfianza injusta,

Dentro del tipo 2, el más numeroso, constatamos un descenso notable del habitual sabor festivo y despreocupado de las mojigangas típicas del XVII. También

\footnotetext{
33 'Logrero': «El que da dinero a logro, y lo mismo que usurero. Dícese también del que compra, o guarda y retiene los frutos, para venderlos después a precio excesivo» (Autoridades, 1734).
} 
de sus planteamientos trasgresores y costumbristas. Se percibe claramente la progresiva apropiación en la mojiganga del enfoque más puramente religioso. Si en el siglo XVII sus desfiles estaban plagados de personajes tipo o figuras simbólicas emparentadas con el ámbito carnavalesco, ahora proliferan los personajes bíblicos o indeterminados pero depositarios de defectos anticristianos que son duramente reprendidos por el coro.

Dentro de los villancicos de mojiganga donde aún se percibe cierta búsqueda de innovación, citamos el villancico IX de la Navidad de 1744. Es un ejemplo un tanto inclasificable en cuanto a su tipología; para empezar, porque el mismo texto se declara como «jácara nueva» aunque luego, formalmente, no lo sea y afirma que está basada en el desfile de personajes:

Coplas

SOLO y COROS. Vayan llegando.

SOLO Y COROS. Vayan viniendo.

Dúo. Varias figuras

de nacimiento,

que es una jácara

de estilo nuevo.

Antón admite y excluye presto.

Posteriormente se puede observar que su argumento se basa en la cólera de Antón, portero del pesebre, motivada por las peticiones frívolas y absurdas que un desfile de personajes está haciendo ante el Niño. Sin embargo, insistimos en que su clasificación tipológica es compleja porque, para empezar, se autodenomina como «jácara nueva»; por otro lado, es innegablemente teatral (y no narrativa como habitualmente eran los villancicos de jácara), puesto que representa a un personaje con todo su carácter paródico (su desmesurada cólera ante las desafortunadas peticiones de los personajes del desfile). Pero este desfile como tal es narrado en estilo indirecto, sin la aparición de los personajes en primera persona ni ningún mote explícito. En todo caso, podríamos encontrar la función del mote puesta en boca del propio Antón cuando los enjuicia:

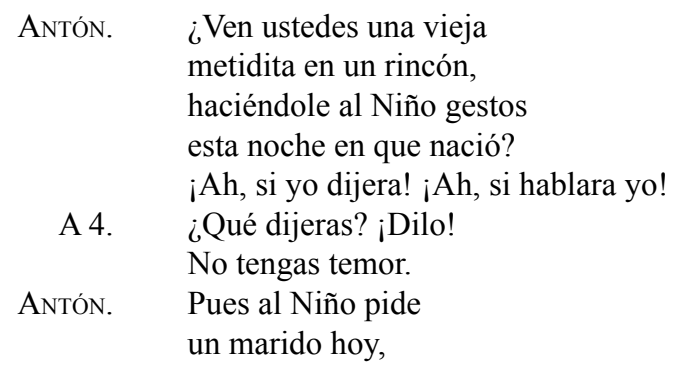


cuando a tres ha muerto con su condición.

ANTÓN. ¿Ven en el portal con pera $^{34}$

un dómine Fantasmón

que afirma que en la Sorbona

seis cátedras se sorbió?

¡Ah, si yo dijera! ¡Ah, si hablara yo!

A 4. No hay que detenerse.

Di, que es diversión.

AnTón. Pues, la dicha pera

toda se ingirió,

en tan gran camueso ${ }^{35}$

que no le hay mayor.

Ejemplo del antiguo gracejo de los villancicos de mojiganga del XVII en los pliegos analizados del XVIII podría ser el villancico VI del pliego de la Navidad de 1736 donde asistimos a un desfile de «visiones» para formar una contradanza ${ }^{36}$ :

1. Vino un doctor dando voces

con bastón de general

y la mula del portal

disparole cuatro coces.

Díjola: «¿No me conoces?».

Y le respondió la mula:

«Antes por conocerle

mis cascos buscan

que les pongan sus hierros

por herradura».

2. Entró en la danza un poeta

de los que quieren glosar

y, así que empezó a bailar,

el buey se irrita y se inquieta,

levantando una soleta, contra un rincón le dispara.

«Si es poeta», le dijo,

34 Dilogía, que va a mantenerse en todo el pasaje, entre la fruta y el valor del término «pera» como «llaman también aquella porción de pelo, que por gravedad se dejan crecer los Eclesiásticos y Doctores en la punta de la barba. Díjose porque ordinariamente es de la hechura de una pera» (Autoridades, 1727).

35 'Camueso' está aquí tomado como el árbol similar al manzano y «metafóricamente se llama así al hombre insensato, tosco, y simple, que no tiene gracia, ni es para nada» (Autoridades, 1729).

36 'Contradanza': «Cierto género de baile nuevamente introducido, que se ejecuta entre seis, ocho, o más personas, formando diferentes figuras y movimientos» (Autoridades, 1729). 
«para glosarla,

ya que un pie dar no puedo

doyle una pata».

Sin embargo, como hemos mencionado, se percibe una nueva tendencia dentro de los villancicos de mojiganga del siglo XVIII: la vinculación de su argumento al entorno religioso. Así pues, los planteamientos más anecdóticos y costumbristas típicos del siglo XVII se van abandonado y se sustituyen por otros de índole más piadosa. Muestra de ello sería, por ejemplo, el villancico IV de la Navidad de 1746, en el que los pastores pretenden ser oficiales de obra para ayudar al Niño a edificar la Iglesia; por ello van a las mejores canteras a recoger piedras. El motor propiciatorio del desfile son los personajes que se acercan a ofrecer piedras y estos no son ya populares o metafóricos sino personajes bíblicos: Esteban, Jacob ${ }^{37}$ y Pedro. Todo el villancico está, pues, construido para subrayar la figura de Pedro como piedra de la iglesia en el pasaje bíblico de Mateo $^{38}$.

$\begin{aligned} & \text { 1. } \begin{array}{l}\text { Piedras para el edificio } \\ \text { trajo costándole a Esteban, } \\ \text { el ver los cielos abiertos } \\ \text { tirarlas para traerla. }\end{array} \\ & \text { 2. } \quad \begin{array}{l}\text { Esas de las manos } \\ \text { partidas se muestran. }\end{array} \\ & \text { Ni a fuerza de sangrar } \\ & \text { el labrarse dejan. } \\ & \text { Pero hará Dios Niño } \\ & \text { por ser las primeras } \\ & \text { que piedras preciosas } \\ & \text { de su casa sean. } \\ & \text { Ande la sierra, ande la sierra, } \\ & \text { que a un tiempo al Dios Niño } \\ & \text { divierte y contempla. } \\ & \text { Jacob de un lugar terrible } \\ & \text { ha conducido una piedra } \\ & \text { habiendo servido antes } \\ & \text { por basa de una escalera. }\end{aligned}$

37 Esteban y Jacob no están elegidos al azar en el texto. San Esteban murió lapidado (Hechos de los apóstoles 6) y Jacob reposó su cabeza sobre una piedra mientras tuvo el sueño profético de una escalera que ascendía hasta Dios (Génesis 28: 10-22). Ambos, pues, tienen una estrecha relación con las piedras que justifica su presencia en el texto y subraya más aún la cada vez más estrecha relación que los villancicos tenían con los textos bíblicos.

38 «Y yo también te digo, que tú eres Pedro, y sobre esta roca edificaré mi iglesia; y las puertas del Hades no prevalecerán contra ella» (Mateo 16: 18). 


\begin{tabular}{|c|c|}
\hline 2. & Ya es esa sacada \\
\hline 1. & $\begin{array}{l}\text { de antigua cantera. } \\
\text { Aun siendo soñada } \\
\text { no será más buena. }\end{array}$ \\
\hline A 4. & $\begin{array}{l}\text { Aunque es buena, el Niño } \\
\text { no se sirve de ella, } \\
\text { que nada hay de antiguo } \\
\text { en fábrica nueva. }\end{array}$ \\
\hline $\begin{array}{r}\text { Todos. } \\
1 .\end{array}$ & $\begin{array}{l}\text { Ande la sierra, etc. } \\
\text { Pedro de una piedra sola } \\
\text { asegura la firmeza, } \\
\text { tanto que sea cimiento } \\
\text { en que se funde la iglesia. }\end{array}$ \\
\hline 2. & $\begin{array}{l}\text { No sé si al labrarse } \\
\text { tendrá alguna quiebra. }\end{array}$ \\
\hline 1. & $\begin{array}{l}\text { De ser firme ha hecho } \\
\text { el Niño la prueba. }\end{array}$ \\
\hline A 4. & $\begin{array}{l}\text { Y del edificio } \\
\text { la máquina excelsa } \\
\text { con tal piedra puede } \\
\text { lograr ser eterna. }\end{array}$ \\
\hline Todos. & Ande la sierra, etc. \\
\hline 1. & $\begin{array}{l}\text { Para clave de la obra } \\
\text { piedra angular la más bella, } \\
\text { el señor, como nacida } \\
\text { en ese portal, nos muestra. }\end{array}$ \\
\hline 2. & $\begin{array}{l}\text { Pues, ¿por qué se labra } \\
\text { con ser tan perfecta? }\end{array}$ \\
\hline 1. & $\begin{array}{l}\text { Porque como todas } \\
\text { en la obra aparezca. }\end{array}$ \\
\hline A 4 . & $\begin{array}{l}\text { Y en las duraciones } \\
\text { tan única sea, } \\
\text { que piedra en eterno } \\
\text { la admire la tierra. }\end{array}$ \\
\hline Todos. & $\begin{array}{l}\text { Ande la sierra, ande la sierra, } \\
\text { que a un tiempo al Dios Niño } \\
\text { divierte y contempla. }\end{array}$ \\
\hline
\end{tabular}

Esta relación cada vez más estrecha con los textos sagrados es una de las tendencias que, de manera general, observamos en el estudio del villancico en el siglo XIX (Llergo, en prensa). En un intento por salvar al villancico de las críticas de sus detractores, sus creadores lo fueron alejando cada vez más de los gustos del público popular volviéndolo poco a poco cada vez más elitista y decoroso hasta llegar a la circunspección. Pero este nuevo talante del villancico, obviamente, no 
debía de satisfacer tanto a los fieles y, por lo tanto, el género perdió su efecto de reclamo que había sido también la causa principal de su aparición.

\section{Conclusiones}

El villancico de mojiganga es una de las tipologías de villancico con más sabor popular, pues conecta directamente con las formas y planteamientos de la fiesta callejera de la que toma su nombre. Tal vez esta sea la principal razón por la que, a lo largo de su trayectoria, también ha demostrado ser una de las formas de villancico paralitúrgico que más divergencia presentaba con los contenidos puramente religiosos. Por otro lado, el género villanciquero fue proclive a satisfacer los gustos y preferencias de su público, mostrándose siempre dispuesto a complacerlos. No olvidemos que el motivo de su introducción en las liturgias fue precisamente atraer a los fieles a las ceremonias, aliviando las largas ceremonias en latín, con canciones en romance de pretendido sabor popular. Esta predisposición fue también la causa de la, en muchos casos, excesiva permisividad con los temas y formas sobre los que se construía el género; muchas veces más propios de un tablado teatral que del suelo de una iglesia.

En este contexto, nos topamos con la preferencia que los fieles asistentes a las ceremonias de Navidad y Epifanía en el Monasterio de las Descalzas debían de sentir por esta tipología de villancico. Para constatar el dato, basta revisar la frecuencia de aparición que los villancicos de mojiganga ostentan entre los pliegos conservados de esta institución durante el siglo XVII en contraste con otras instituciones similares como pueden ser la Real Capilla y el Monasterio de la Encarnación.

Pero el público villanciquero, en general, era exigente. No solo pedía villancicos de mojiganga, sino que estos fueran nuevos cada año en cada festividad que los incluía. Así pues, los villancicos de mojiganga de nuestro corpus en el siglo XVII son claro ejemplo de una búsqueda incesante de novedad. Sus textos, como hemos visto, sorteaban los límites de lo permitido y eran claros ejemplos de transgresión en sus formas y sus temas, alejándose estos, en muchos casos, de los temas religiosos propios de las festividades en las que estaban inmersos.

El panorama del siglo XVIII es, sin embargo, bien distinto, aunque indicativo de la tendencia general que marcó a este género durante el Siglo de las Luces y que inicia su declive hasta su práctica desaparición en el XIX. Los villancicos de más sabor popular, de innegable parentesco teatral con los subgéneros teatrales breves y de temas más alejados de lo puramente religioso, van siendo sustituidos (aunque paulatinamente) por otras formas más cultas y elitistas (las italianas), también teatrales pero vinculadas más a lo operístico que al teatro castizo español. Para no perder su amarre con el público, al lado de estas formas cultas y elitistas aparecen otras nuevas, como la pastorela o la tonadilla, de sabor popular, pero de carga 
mucho menos transgresora que los villancicos de mojiganga. Pero la sustitución gradual de los villancicos de mojiganga (y otras formas de villancico más transgresoras) por formas más ortodoxas, no fue la única manera de acallar los flirteos de esta tipología con lo profano. Los propios villancicos de mojiganga experimentaron cambios temáticos y formales para adaptarse también a las exigencias de los críticos acercando sus argumentos cada vez más a los textos sagrados.

Todas ellas fueron medidas paliativas para combatir las cada vez más estentóreas voces de la crítica. Pero al mismo tiempo, como ya hemos apuntados en otros estudios (Llergo, en prensa), firmó la sentencia de muerte de este peculiar género pues, poco a poco, le fue despojando de su mayor encanto que, al mismo tiempo, era su seña de identidad y razón de existencia: su vinculación directa a los gustos del pueblo.

Así pues, el corpus analizado de villancicos de mojiganga del Monasterio de las Descalzas confirma una tendencia general en el villancico paralitúrgico: cómo las transgresiones que le fueron permitidas a este género fueron su máxima seña de identidad y causa de su éxito y, al mismo tiempo, acabaron configurando su sentencia de muerte.

\section{Corpus de Villancicos estudiados}

\subsection{SigLo XVII}

Villancicos al Santísimo Sacramento que en su fiesta ha de cantar la Capilla de las Descalcas [sic] Reales de esta Corte, este año de 1678. Madrid?: [s.e.], 1678? [BNE, VE/ 88-54].

Villancicos que se cantaron en el Real Convento de las Descalzas la noche de Navidad deste año MDCLXXIX. Madrid?: [s.e.], 1679? [BNE, VE/83-44].

Villancicos que se han de cantar en la Real Capilla de las Descalzas la noche de Navidad este año de 1680. Madrid: Mateo Espinosa y Arteaga, 1680 [BNE, VE/83-45].

Villancicos que se cantaron en la Capilla Real de las señoras Descalzas la noche de Navidad de 1682 y la de... Reyes de 1683. Madrid?: [s.e.], 1683? [BNE, VE/79-1].

Villancicos que se han de cantar en la Real Capilla de las señoras Descalzas la noche de Navidad, este año de 1683 y la de Reyes de 1684. Madrid: Antonio Zafra, 1683? [BNE, VE/79-2].

Villancicos que se han de cantar en la Real Capilla de las señoras Descalzas la noche de Navidad, este año de 1684 y la de Reyes de 1685. Madrid: Antonio Zafra, 1684? [BNE, VE/79-3].

Villancicos que se han cantaron en la Real Capilla de las señoras Descalzas la noche de Navidad, este año de 1685 y la de Reyes de 1686. Madrid: Antonio Zafra, 1686? [BNE, VE/79-4]. 
Villancicos que se han de cantar la noche de Navidad en la Real Capilla de las señoras Descalzas. Madrid: Melchor Álvarez, 1688 [BNE, VE/83-46].

Villancicos que se han de cantar la noche de Navidad en la Real Capilla de las señoras Descalzas. Madrid: [s.e.], 1689? [BNE, VE/83-47].

Villancicos que se han de cantar la noche de los Santos Reyes en la Real Capilla de las Señoras Descalzas este año de M.DC.LXXXX. Madrid: Melchor Álvarez, 1690? [BNE, VE/77-12].

Villancicos que se han de cantar la noche de Navidad, en la Real Capilla de las Señoras Descalzas este año de 1690. Madrid: Melchor Álvarez, 1690? [BNE, VE/83-48].

Villancicos que se han de cantar la noche de Navidad en la Real Capilla de las señoras Descalzas este año de 1691. Madrid: Melchor Álvarez, 1691? [BNE, R/34988 (10)].

Villancicos que se han de cantar la noche de Navidad, en la Real Capilla de las señoras Descalzas, este año de M.DC.LXXXXII. Madrid: Melchor Álvarez, 1692? [BNE, $\mathrm{R} / 34988$ (11)].

Villancicos que se han de cantar la noche de Navidad en la Real Capilla de las Señoras Descalzas este año de M.DC.LXXXXIII. Madrid: Melchor Álvarez, 1693? [BNE, $\mathrm{VE} / 83-51]$.

Villancicos que se han de cantar la noche de Navidad, en la Real Capilla de las Señoras Descalzas este año de 1694. Madrid: Manuel Ruiz de Murga, 1694? [BNE, $\mathrm{R} / 34988$ (12)].

Villancicos que se han de cantar la noche de Navidad, en la Real Capilla de las Señoras Descalzas este año de 1695. Madrid: Manuel Ruiz de Murga, 1695? [BNE, $\mathrm{R} / 34988$ (13)].

Villancicos que se han de cantar la noche de Navidad, en la Real Capilla de las Señoras Descalzas este año de 1696. Madrid: Manuel Ruiz de Murga, 1696? [BNE, $\mathrm{R} / 34988$ (14)].

Villancicos que se han de cantar la noche de Navidad, en la Real Capilla de las Señoras Descalzas este año de 1699. Madrid: Manuel Ruiz de Murga, 1699? [BNE, $\mathrm{R} / 34988$ (15)].

\subsection{SigLO XVIII}

Villancicos que se han de cantar en los Maitines de... Reyes, en la Real Capilla de las Señoras Descalzas este año de 1700. Madrid?: En la imprenta de Manuel Ruíz de Murcia, 1700? [BNE, VE/77/51].

Villancicos, que se han de cantar la noche de Navidad en la Real Capilla de las señoras Descalzas, este año de 1701. Madrid?: En la imprenta de Manuel Ruíz de Murcia, 1701 ? [BNE, VE/1327/43].

Villancicos, que se han de cantar la noche de Navidad en la Real Capilla de las Señoras Descalzas, este año de MDCCIII. Madrid?: En la imprenta de Manuel Ruíz de Murcia, 1703? [BNE, VE/1327/44]. 
Villancicos, que se han de cantar la noche de Navidad en la real Capilla de las señoras Descalzas, este año de 1708. Madrid?: [s.e.], 1708? [BNE, VE/1327/45].

Letras de los villancicos, que se han de cantar en esta Real Capilla de las Señoras Descalzas, la víspera, y día de San Juan Bautista, en la profesión de la señora Soror Tomasa María de Santa Clara... Madrid?: [s.e.], 1708? [BNE, VE/533/24].

Villancicos, que se han de cantar en los Maitines de los Santos Reyes, en la Real Capilla de las señoras Descalzas, este año de 1710. Madrid?: En la imprenta de Manuel Ruíz de Murcia, 1710? [BNE, VE/1327/46].

Villancicos, que se han de cantar la noche de Navidad en la Real Capilla de las señoras Descalzas este año de 1711. Madrid?: [s.e.], 1711? [BNE, VE/1327/47].

Villancicos, que se han de cantar la noche de Navidad, en la Real Capilla de las señoras Descalzas, este año de 1713. Madrid?: En la imprenta de Manuel Ruíz de Murcia, 1713? [BNE, VE/1327/48].

Villancicos, que se han de cantar la noche de Navidad en la Real Capilla de las Señoras Descalzas este año de 1714. Madrid?: En la imprenta de Manuel Ruíz de Murcia, 1714? [BNE, VE/1327/49].

Villancicos, que se han de cantar la noche de Navidad en la Real Capilla de las Señoras Descalzas este año de 1715. Madrid?: En la imprenta de Manuel Ruíz de Murcia, 1715? [BNE, VE/1327/50].

Villancicos, que se han de cantar la noche de Navidad, en la Real Capilla de las señoras Descalzas este año de 1720. Madrid?: En la imprenta de los Herederos de Manuel Ruiz de Murga, 1720? [BNE, VE/708/52].

Villancicos, que se han de cantar la noche de Navidad, en la Real Capilla de las señoras Descalzas este año de MDCCXXII. Madrid?: En la imprenta de Felipe Alonso, 1722? [BNE, VE/1327/51].

Villancicos, que se han de cantar la noche de Navidad, en la Real Capilla de las Señoras Descalzas este año de 1723. Madrid?: En la imprenta de Felipe Alonso, 1723? [BNE, VE/1306/41].

Villancicos, que se han de cantar la noche de Navidad, en la Real Capilla de las señoras Descalzas este año de MDCCXXV. Madrid?: En la imprenta de Felipe Alonso, 1725? [BNE, VE/1306/47].

Villancicos, que se han de cantar la noche de Navidad, en la Real Capilla de las señoras Descalzas este año de MDCCXXVI. Madrid?: En la imprenta de Felipe Alonso, 1726? [BNE, VE/1306/58].

Villancicos, que se han de cantar la noche de Navidad, en la Real Capilla de las señoras descalzas este año de MDCCXXVIII. Madrid?: En la imprenta de Felipe Alonso, 1728? [BNE, VE/1306/66].

Villancicos, que se han de cantar la noche de Navidad en la Real Capilla de las señoras descalzas, este año de MDCCXXXII. Madrid?: En la imprenta de Felipe Alonso, 1732? [BNE, VE/1306/79].

Villancicos, que se han de cantar la noche de Navidad en la Real Capilla de las señoras descalzas, este año de MDCCXXXIII. Madrid?: En la imprenta de Felipe Alonso, 1733? [BNE, VE/1306/86]. 
Villancicos, que se han de cantar la noche de Navidad en la Real Capilla de las señoras descalzas, este año de MDCCXXXIV. Madrid?: En la imprenta de Diego Miguel de Peralta, 1734? [BNE, VE/1306/91].

Villancicos, que se han de cantar la noche de Navidad en la Real Capilla de las señoras Descalzas Reales, este año de MDCCXXXVI. Madrid?: En la imprenta de Diego Miguel de Peralta, 1736? [BNE, VE/1307/21].

Villancicos, que se han de cantar la noche de Navidad en la Real Capilla de las señoras Descalzas Reales, este año de MDCCXXXVII. Madrid?: En la imprenta de Diego Miguel de Peralta, 1737? [BNE, VE/1307/25].

Villancicos, que se han de cantar la noche de Navidad en la Real Capilla de las señoras Descalzas Reales este año de MDCCXXXVIII. Madrid?: En la imprenta de Diego Miguel de Peralta, 1738? [BNE, VE/1307/29].

Villancicos, que se han de cantar la noche de Navidad en la Real Capilla de las señoras Descalzas Reales este año de MDCCXXXIX. Madrid?: En la imprenta de Diego Miguel de Peralta, 1739? [BNE, VE/1307/35].

Villancicos, que se han de cantar la noche de Navidad de la Real Capilla de las Señoras Descalzas Reales, este año de MDCCXL. Madrid?: En la imprenta de Diego Miguel de Peralta, 1740? [BNE, VE/1307/37].

Villancicos, que se han de cantar la noche de Navidad en la Real Capilla de las señoras Descalzas Reales, este año de MDCCXLI. Madrid?: En la imprenta de la viuda de Peralta, 1741? [BNE, VE/1307/39].

Villancicos, que se han de cantar la noche de Navidad en la Real Capilla de las Señoras Descalzas Reales este año de 1743. Madrid?: En la imprenta de la viuda de Peralta, calle de la Habada, 1743? [BNE, VE/1443/24].

Villancicos, que se han de cantar la noche de Navidad en la Real Capilla de las... Descalzas Reales, este año de MDCCXLIV. Madrid?: En la imprenta de la viuda de Peralta, 1744? [BNE, 3/60932 (6)].

Villancicos, que se han de cantar la noche de Navidad, en la Real Capilla de las señoras Descalzas Reales, este año de MDCCXLV. Madrid?: En la imprenta de la viuda de Peralta, 1745? [BNE, 3/60932 (5)].

Villancicos, que se han de cantar la noche de Navidad en la Real Capilla de las señoras Descalzas Reales, este año de MDCCXLVI. Madrid?: En la imprenta de la viuda de Peralta, impresora de las... Descalzas Reales, 1746? [BNE, VE/1327/52].

Villancicos, que se han de cantar la noche de Navidad, en la Real Capilla de las señoras Descalzas Reales, este año de MDCCXLVII. Madrid?: En la imprenta de la viuda de Peralta, 1747? [BNE, VE/316/16].

Villancicos, que se han de cantar la noche de Navidad, en la Real Capilla de las señoras Descalzas Reales, este año de MDCCXLVIII. Madrid?: En la imprenta de la viuda de Peralta, 1748? [BNE, VE/1307/49].

Villancicos, que se han de cantar la noche de Navidad, en la Real Capilla de las señoras Descalzas Reales, este año de MDCCXLIX. Madrid?: En la imprenta de la viuda de Peralta, 1749? [BNE, VE/1307/51]. 


\section{BIBLIOGRAFÍA}

Buezo, Catalina (1991). La mojiganga dramática. Historia y teoría. Madrid: Universidad Complutense de Madrid.

Buezo, Catalina (2005). La mojiganga dramática: de la fiesta al teatro. Kassel: Reichenberger.

García Mercadal, José (ed.) (1999). Viajes de extranjeros por España y Portugal desde los tiempos más remotos hasta fines del siglo XVI. Valladolid: Junta de Castilla y León.

Huerta, Javier y José Luis Alonso Hernández (2000). Historia de mil y un Juanes: onomástica, literatura y folclore. Salamanca: Ediciones Universidad de Salamanca.

LLERGO, Eva (2012). «Representación y representabilidad en los villancicos paralitúrgicos de las Descalzas Reales». eHumanista, 21, pp. 132-161.

Llergo, Eva (2013). «Rasgos de teatralidad de los villancicos paralitúrgicos barrocos del Monasterio de la Encarnación de Madrid». En José M. ${ }^{a}$ Díez Borque (dir.), M. ${ }^{a}$ Soledad Arredondo Sirodey, Ana Martínez Pereira, Gerardo Fernández San Emeterio (eds.), Teatro español de los siglos de Oro. Dramaturgos, textos, escenarios, fiestas. Madrid: Cátedra.

Llergo, Eva (2017). El villancico paralitúrgico: un género en su contexto. Santander: Sociedad Menéndez Pelayo.

Llergo, Eva [en prensa]. «Siglo XIX: ¿el final del villancico (paralitúrgico)». En Esther Borrego y Javier Marín (dirs.), Nuevas perspectivas en torno al villancico en el mundo ibérico (siglos $X V$-XIX). Kassel: Reichenberger.

Pérez Mora, Rosario (2006). La tonadilla en el espejo. El villancico de tonadilla y sus analogías con las tonadillas teatrales dieciochescas [tesina de doctorado]. Universidad Complutense de Madrid.

Ramos, Pilar (2007). «Pastorelas and the Pastoral Tradition in 18th-Century Spanish Villancico». En Tess Knighton y Álvaro Torrente (eds.), Devotional Music in the Iberian World, 1450-1800. The Villancico and Related Genres. Aldershot, UK: Ashgate, pp. 283-306.

SÁNCHEZ Siscart, Montserrat (1989-90). «Evolución formal del villancico y el oratorio dieciochesco en las catedrales aragonesas». Recerca Musicológica, 9-10, pp. 327-340.

Stevenson, Robert (1960). Spanish Music in the Age of Columbus. The Hague: Martinus Nijhoff. DOI https://doi.org/10.1007/978-94-011-9438-9.

Torrente, Álvaro (2009). «The Early History of Villancico Libretti». Sicientific Researchers, Musicology today: problems and perspectives. Ukranian National Tchaikovsky Academy of Music, 80, pp. 326-336.

Torrente, Álvaro (2010). «"Misturadas de castelhanadas como oficio divino": la reforma de los maitines de Navidad y Reyes en el s. XVIII». En Miguel Ángel Marín (ed.), 
La ópera en el templo: Estudios sobre el compositor Francisco Javier García Fajer. Logroño / Zaragoza: Instituto de Estudios Riojanos / Institución Fernando el Católico, pp. 193-235.

Recibido: 22/05/2018

Aceptado: 20/06/2018

Los Villancicos de mojiganga del Monasterio de las Descalzas:

LOS LÍMITES DE LA TRANSGRESIÓN

Resumen: El artículo analiza la evolución, desde el siglo XVII al XVIII, de una tipología concreta de villancico dentro del corpus de los conservados en el madrileño Monasterio de las Descalzas: los villancicos de mojiganga. De innegable talante teatral, este tipo de villancicos fueron los favoritos del público de las Descalzas, y quizás esto provocó que fuera transgredido ostensiblemente en muchas ocasiones el espíritu religioso que debía imbuirlos. Su estudio ofrece no solo un fiel retrato de este género a lo largo de dos siglos, sino la constatación de la tendencia que experimentó a lo largo de su trayectoria vital: una fuerte censura que acabó por destruir su esencia.

Palabras Clave: villancicos, mojigangas, siglos XVII-XVIII, Monasterio de las Descalzas.

THE VILLANCICOS DE MOJIGANGA OF THE MONASTERIO DE LAS DESCALZAS: THE LIMITS OF TRANSGRESSION

ABSTRACT: The article analyzes the evolution, from the seventeenth to the eighteenth century, of a specific typology of villancico in the preserved corpus of the Monasterio de las Descalzas in Madrid: the villancico de mojiganga. Undeniably theatrical, this type of villancico was the favourite of the Descalzas' public, and it could often have led to an obvious transgression of the religious spirit that should had imbued them. Its study offers, not only a faithful portrait of this genre over two centuries, but the verification of the trend it experienced throughout its trajectory: a strong censorship that ended up destroying its essence.

KEYWORDS: villancicos, mojigangas, seventeenth and eighteenth century, Monasterio de las Descalzas. 


\section{Edad de Oro. Revista de Filología Hispánica}

ISSN: 0212-0429 - ISSNe: 2605-3314 <https://revistas.uam.es/edadoro/index>

Edad de Oro es uno de los máximos referentes en el área de investigación en Filología Hispánica, especialmente de los siglos XVI y XVII. Goza de un amplio reconocimiento en el ámbito académico internacional. Desde 1982 publica ininterrumpidamente, con una periodicidad anual, colaboraciones científicas de los principales especialistas de diversos centros nacionales y extranjeros. Con un público compuesto esencialmente por investigadores y expertos de todo el mundo, se dirige a cualquier persona interesada en las nuevas corrientes de los estudios humanísticos de su campo.

Dirección:

María Jesús Zamora Calvo

(Univ. Autónoma de Madrid)

Subdirección:

José Antonio Llera Ruiz

(Univ. Autónoma de Madrid)

Secretaría:

Raquel Arias Careaga

(Univ. Autónoma de Madrid)

Consejo de redacción:

Cecilia López-Ridaura

(ENES. Morelia / Univ. Nacional

Autónoma de México)

José Luis Ocasar Ariza

(Univ. Autónoma de Madrid)

Rocío Pérez Gironda

(Univ. Autónoma de Madrid)

Carolina Fernández Cordero

(Iberoamericana-Vervuert)

Admisión de originales:

María Jesús Zamora Calvo

Edad de Oro

Universidad Autónoma de Madrid

Facultad de Filosofía y Letras

Departamento de Filología Española

Campus Cantoblanco

28049 Madrid (España)

Tfno. (+34) 914976886

Correo-e: mariajesus.zamora@uam.es

Distribución, suscripción y venta:

Servicio de Publicaciones de la UAM

Universidad Autónoma de Madrid

28049 Madrid (España)
Intercambio de publicaciones:

Biblioteca de Humanidades

Universidad Autónoma de Madrid

28049 Madrid (España)

Comité científico:

Carlos Alvar (Université de Gèneve)

Ignacio Arellano (Univ. de Navarra)

Alberto Blecua

(Univ. Autónoma de Barcelona)

Jean Canavaggio

(Université Paris Nanterre)

Aurora Egido (Univ. de Zaragoza)

Víctor García de la Concha (RAE)

Luciano García Lorenzo (CSIC)

Joaquín González Cuenca

(Univ. de Castilla la Mancha)

Agustín de la Granja López

(Univ. de Granada)

Begoña López Bueno (Univ. de Sevilla)

Michel Moner

(Universitè Toulouse - Jean Jaurès)

Joan Oleza (Univ. de Valencia)

Alfonso Rey

(Univ. de Santiago de Compostela)

Lina Rodríguez Cacho

(Univ. de Salamanca)

Leonardo Romero Tobar

(Univ. de Zaragoza)

Aldo Ruffinatto

(Università degli Studi di Torino)

Lía Schwartz

(City University of New York)

Han colaborado en este volumen:

Departamento de Filología Española

(UAM)

Facultad de Filosofía y Letras (UAM)

Edad de Oro se recoge en las siguientes bases de datos y directorios: DICE; HLAS; MLA International Bibliography; PIO; ISOC-CSIC; DIALNET; SUMARIS CBUC; ULRICH'S.

Se encuentra evaluada en: SCOPUS: Q2; SCImago: SJR 2017 0.11, H Index 4; ERIH Plus: category A; CIRC: categoría C; RESH: 0.162; MIAR: ICDS 2017 10.0; CARHUS Plus+: C; LATINDEX. 


\section{EDAD DE ORO}

Revista de Filología Hispánica XXXVII

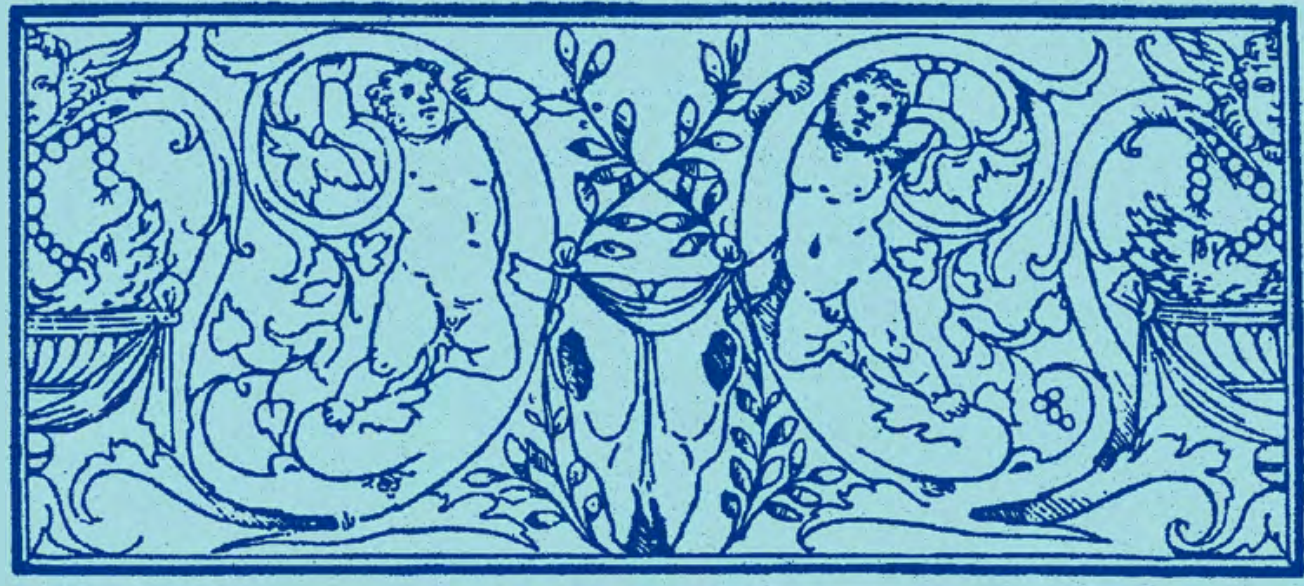

\section{DEPARTAMENTO DE FILOLOGÍA ESPAÑOLA}

EDICIONES DE LA UNIVERSIDAD AUTÓNOMA DE MADRID 